\title{
A RENOVAÇÃO DO DIREITO AGRÁRIO E OS GUILOMBOS: IDENTIDADE, TERRITÓRIO E DIREITOS CULTURAIS*
}

César Augusto Baldi**

\section{Resumo}

A discussão envolvendo quilombolas e comunidades tradicionais vêm sendo incorporada, aos poucos, no âmbito da disciplina de Direito Agrário. Trata-se de analisar a emergência de temas e questões que foram silenciados, negligenciados ou tidos como existentes. Para tanto, em intersecç̧ão com a antropologia jurídica, o direito internacional de direitos humanos e o direito da antidiscriminação, procurase verificar os caminhos de investigação que tais comunidades permitem renovar o estudo do Direito Agrário.

Palavras-chave: Princípio da igualdade. Direito internacional dos direitos humanos. Comunidades tradicionais. Antropologia jurídica.

\begin{abstract}
"Nós, os povos de origem africana que vivemos nestes territórios do norte de Esmeraldas, nos assumimos de raízes ancestrais, não só porque chegamos quando ninguém podia chegar, mas também porque chegamos para fazer que esses territórios sejam o que são agora. Sem nossa presença aqui, estas terras seriam qualquer coisa, exceto espaço para conservação e para vida" (SALAZAR, 2010, p. 63)
\end{abstract}

\section{Introdução}

Embora a temática indígena já esteja incorporada no âmbito da disciplina de Direito Agrário, a discussão sobre populações quilombolas e outras populações tradicionais ainda não vem sendo tratada pelos autores nacionais, mesmo com o acirramento de conflitos fundiários e com os projetos de desenvolvimento país afora. Trata-se de uma efetiva ausência, até certo ponto ativamente produzida como tal.

* Palestra realizada no II Congresso Internacional de Direito Agrário- "Sujeitos da/na América Latina: comunidades tradicionais e natureza", no painel "Questão quilombolaidentidade, território e direitos culturais", no dia 12 de setembro de 2013 na Universidade Federal de Santa Catarina, Florianópolis.

** Mestre em Direito pela Universidade Luterana do Brasil/RS, doutorando Universidad Pablo Olavide (Espanha), é organizador do livro "Direitos humanos na sociedade cosmopolita” (Ed. Renovar, 2004). cesarbaldi@msn.com

R. Fac. Dir. UFG, V. 37, n. 02, p. 196 - 234, jul. / dez. $2013 \quad$ ISSN 0101 - 7187 
A partir da incorporação deste tema no âmbito do Direito Agrário, busca-se ampliar as possibilidades de discussão, alargando o âmbito de estudo da disciplina, com incorporação de contribuições da Antropologia Jurídica, do Direito Internacional de Direitos Humanos e do Direito Constitucional, na vertente do tratamento do princípio da igualdade.

\section{O campo de estudos do Direito Agrário}

Para Raymundo Laranjeira, (2004, p. 136-164) as questões agrárias sempre "tiveram um trato inferiorizado, pelo nosso legislador", no sentido de uma "história agrária e controlada pelas forças latifundiárias, oligárquicas ou burguesas, e hoje comandada pelos padrões de um capitalismo brutalizante e mais conturbador". A própria denominação da disciplina, neste sentido, variou- ora "fundiário", ora "agrário", ora "rural”.

Segundo Benedito Ferreira Marques, (2007, p. 03) é preferivel a denominação "agrário" como "campo suscetível de produção ou destinado à exploração", destacando o caráter dinâmico, ao passo que rural tem conotação estática. A nomenclatura- e, pois, a autonomia legislativa- se deu por força da EC $\mathrm{n}^{\circ} 10$, de 10/10/64 (que introduziu a alínea "a" ao inciso XV do art. $5^{\circ}$ da Constituição de 1946) e se mantém, na Constituição atual, no art. 22, I, como "competência privativa da União". Para o autor acima citado, é necessário enfatizar "a atividade agrária como centro das preocupações, na medida em que somente por elas se oportuniza a relação homem-terra", mas atribuir "função social da terra", ainda mais no novo sistema constitucional. Daí porque saliente, dentre os princípios do Direito Agrário, (Idem, p. 05) tanto a utilização da terra se sobrepondo à titulação dominial, quanto: a) garantia da propriedade da terra, mas condicionada ao cumprimento da função social; b) a conservação e preservação dos recursos naturais e proteção do meio ambiente; c) o dimensionamento eficaz das áreas exploráveis; d) a reformulação da estrutura fundiária como necessidade constante; e) proteção à propriedade familiar, à pequena e média propriedade. 
Isso significa, no dizer de Carlos Marés, que o "Direito Agrário nasce sob o signo do uso adequado da terra, da produção, da ocupação, do fim da possibilidade do proprietário não utilizar sua propriedade, nasce com missão emancipatória." (SOUZA FILHO, 1999, p. 509) E, desta forma, o "problema já não é mais saber se ela deve ter uma função social, mas em medida a proteção ao meio ambiente o determina." "Nesse sentido, portanto, a propriedade produtiva é aquela que cumpre sua função social, ou seja, que obedece os requisitos do art. 186 da Constituição: a) aproveitamento racional e adequado; b) utilização adequada dos recursos naturais disponíveis e preservação do meio ambiente; c) observância das disposições que regulam as relações de trabalho ${ }^{2}$; d) exploração que favoreça o bem-estar dos proprietários e dos trabalhadores.

Diante disso, Marés vai afirmar que a proteção ambiental impregna todas as latitudes do Direito Agrário e "cada capítulo novo que surge no vasto espectro da questão ambiental, sempre coletivo e por isso novo para um Direito fundado no princípio individual" (Idem, p. 518), o modifica, o atualiza, incorporando novos temas, como transgênicos, acesso ao conhecimento das populações tradicionais, etc. As conexões com o Direito ambiental, em sua versão socioambiental, são, portanto, evidentes.

Apesar disso, verifica-se que os livros que tratam do tema dão especial atenção à questão indígena: para Raymundo Laranjeira, a "situação jurídica da terra indígena" é "inquestionavelmente estudada pelo Direito agrário", embora "conformada à luz da conveniência da sociedade envolvente, não na conformidade das idiossincrasias do índio.” (LARANJEIRA, 2004, p. 32) Daí sua ideia de que devese "respeitar a gestão de bens pela própria comunidade indígena, o patrimônio gerido pelo próprio índio, com os rendimentos revertidos no seu exclusivo benefício" (Idem, p. 202), ainda que entendendo que a tutela é "o que dá ainda alguma segurança aos nossos autóctones." ${ }^{3}$ É pacífico, pois, que o tema integra o estudo de Direito Agrário.

Mas, no geral, não se avança em relação a discussões de outras formas de posse ou propriedade. De fato, ausente nos livros, no geral, o conceito de "posse 
agroecológica” (ROCHA, 2010, p. 86), vinculando os arts. 215, § 1º, 216 e 225 da Constituição, em que: a) o corpus consistiria na "apreensão imediata e direta sobre o imóvel, mas não necessariamente exclusivista sobre as áreas de uso comum e os recursos naturais, refletindo na manutenção de sua sustentabilidade ambiental"; b) o animus seria representado por "identificar o local onde a comunidade vive para além do simples espaço onde reside, mas sem que isso importe a intenção imediata de exercer o direito de propriedade como se fosse seu titular" e de "forma exclusiva."

A "posse agroecológica", assim, seria uma "especial forma de relação com a terra", compatibilizando "posse e restrições em defesa do meio ambiente", tomando por uso comum "determinados bens ambientais com práticas de manejo que permitem a sustentabilidade do uso dos recursos naturais." 4

Nesta perspectiva, a "posse agroecológica" tem espaço dentro das unidades de conservação, e o que "justifica o exercício do direito à propriedade ou à posse nestas áreas é a relação direta com o objeto": não é a "propriedade enquanto domínio que legitima a posse, mas "a posse, o uso efetivo do bem, como utilidade social, é que legitima a propriedade ou domínio". (Idem, p. 85) Nestes casos, devem-se valorizar as "populações tradicionais", entendidas como:

Populações [...] que possuem como características uma existência baseada em sistemas sustentáveis de exploração dos recursos naturais, desenvolvidos ao longo de gerações e adaptados às condições ecológicas locais e que desempenham um papel fundamental na proteção da natureza e na manutenção da diversidade biológica.

O conceito de "populações tradicionais", previsto originalmente no art. 20 da Lei do SNUC, vai além das reservas de desenvolvimento sustentável. É nesse contexto que vão ser reconhecidas "posses étnicas": a indígena, com fundamento nos arts. 231 e 232 da Constituição, com o diferencial de ser originária ${ }^{5}$; e a posse quilombola, tal como prevista no art. 68 do ADCT. Esta, por sua vez, seria (Idem, p. 99): 
Uma posse étnica que surge a partir de uma determinada forma de apossamento de uma área e seus recursos naturais por um agrupamento descendente de negros cujos antepassados foram escravos, em que a identidade é elemento fundamental na garantia desse direito pelo legislador, e também é uma modalidade de posse agroecológica porque há a apropriação familiar da terra ou dos recursos naturais, dentro de um contexto comunitário.

Observe-se, contudo, que, aqui, trata-se de uma titulação coletiva de domínio, ao passo que na "posse indígena", segundo a Constituição, a propriedade continua sendo da União, ainda que o usufruto seja dos povos indígenas. Vale dizer: ainda que tenha avançado em relação às Constituições anteriores, a questão indígena evidencia uma "situação de tutela" relativa.

Isso, por sua vez, coloca alguns desafios para a renovação do Direito Agrário, que, ainda de forma muito tímida, coloca o tema das "populações tradicionais" e "quilombolas" como estudo da disciplina. Apesar de algumas legislações estaduais 6 : a) os direitos dos núcleos familiares que ocupam áreas de barreiras e "áreas de várzeas" (arts. 250 e 251 da Constituição estadual do Amazonas, de 1989); b) o direito real de concessão de uso nas áreas de fundo de pasto (art. 178 da Constituição estadual da Bahia, de 1989); c) a exploração dos babaçuais em regime de economia familiar e comunitária (art. 196 da Constituição estadual do Maranhão, de 1990), com diversas leis municipais de "babaçu livre" nos Estados do Maranhão, Tocantins e Pará (livre acesso e uso comum das palmeiras de babaçu pelas quebradeiras de coco e suas famílias, estejam em domínio público ou privado) (SHIRASHI NETO, 2005); d) o reconhecimento dos "faxinais" como "sistema de produção camponês tradicional, característico da região Centro-Sul do Paraná, que tem como traço marcante o uso coletivo da terra para produção animal e conservação ambiental" (art. $1^{\circ}$ da Lei n 3.446, de 1997, do Estado do Paraná) (ALMEIDA, 2009); e) o procedimento de regularização das terras quilombolas, em especial com o Decreto $n^{\circ} 4.887 / 2003$ e legislações estaduais. ${ }^{7}$. Além da criação da Política Nacional para os Povos e Comunidades Tradicionais, com a edição do Decreto $\mathrm{n}^{\circ}$ 6.040/2007, e a respectiva Comissão Nacional. 8 
Esta renovação, portanto, necessita partir destas questões: a) a pluralidade de conceitos de posses e propriedades; b) a existência de realidades que extrapolam os tradicionais animus e corpus de tais conceitos e, portanto, concepções forjadas dentro de um contexto europeu/moderno/colonial, que precisa ser alargado; c) um processo de etnicidade que envolve a própria apropriação da terra, o que implica reconhecer que esta, em especial com a Lei de Terras de 1850, sempre teve um caráter étnico excludente (ou seja, reconhecer que a apropriação por sujeitos de direito masculinos, colonizadores e brancos tem, também, um caráter étnico e não somente a "posse indígena" e "posse quilombola"); d) reconhecer que "o que não existe é, na verdade, activamente produzido como não existente" (SANTOS, 2002) e, portanto, necessário abrir a discussão para as "terras tradicionalmente ocupadas" e para as populações tradicionais, aí incluídos fundos de pasto, faxinais, ribeirinhos, ciganos, etc.

Lilian Gomes, ao salientar a produção da "não existência das comunidades negras no pós-abolição", recorda um número significativo de estudos voltados para o período da escravidão e, somente a partir da década de 1980, "uma nova tendência que aponta para a preocupação em compreender o fenômeno" em sua "contemporaneidade". A consequência disso foi que "a questão das comunidades negras não foi contemplada pela literatura que pensou a questão agrária do Brasil, sobretudo a partir da década de 1950, quando a luta pela terra se tornou um tema mais recorrente no espaço público.” (GOMES, 2009, p. 174-176)

Trata-se, pois, de não só verificar as ausências no Direito Agrário ${ }^{9}$, mas a emergência de temas e questões que foram silenciados, invisibilizados, negligenciados e tidos como inexistentes. Possível, portanto, esboçar algumas linhas de estudo e de renovação do Direito Agrário, dentro do reconhecimento de "uma diversidade de agrupamentos tornados invisíveis pelas pretensões oficiais de homogeneização jurídica da categoria povo desde o período colonial." (ALMEIDA, 2009, p. 387-388) 


\section{2. "Terras tradicionalmente ocupadas"}

A partir do Decreto $\mathrm{n}^{\circ}$ 6.040/2007, tanto "terras tradicionais" quanto "povos e comunidades tradicionais" estão legalmente previstos e especificados:

I- Povos e Comunidades Tradicionais: grupos culturalmente diferenciados e que se reconhecem como tais, que possuem formas próprias de organização social, que ocupam e usam territórios e recursos naturais como condição para sua reprodução cultural, social, religiosa, ancestral e econômica, utilizando conhecimentos, inovações e práticas gerados e transmitidos pela tradição;

II- Territórios Tradicionais: os espaços necessários a reprodução cultural, social e econômica dos povos e comunidades tradicionais, sejam eles utilizados de forma permanente ou temporária, observado, no que diz respeito aos povos indígenas e quilombolas, respectivamente, o que dispõem os arts. 231 da Constituição e 68 do Ato das Disposições Constitucionais Transitórias e demais regulamentações.

É verdade que, desde o art. 231 da Constituição:

[...] a ocupação permanente de terras e suas formas intrínsecas de uso caracterizam o sentido peculiar de tradicional" e, além de "deslocar a 'imemorialidade', este preceito constitucional contrasta criticamente com as legislações agrárias coloniais”, que criaram obstáculos "de todas as ordens para que não tivessem acesso legal às terras os povos indígenas, os escravos alforriados e os trabalhadores imigrantes que começavam a ser recrutados. (ALMEIDA, 2008. p. 39)

Ao retirar o caráter de "imemorial" e assumir o conceito de "tradicionalmente ocupadas", já havia rompido o parâmetro para entendimento das "terras indígenas".

Mas não é menos importante salientar que "um aspecto frequentemente ignorado da estrutura agrária brasileira refere-se às modalidades de uso comum da terra", situações em que o "controle dos recursos básicos não é exercido livre e individualmente por um determinado grupo doméstico de pequenos produtores diretos ou por um de seus membros." (Idem, p. 133)

Em tais situações (Idem, p. 133-134): a) o controle se dá através de "normas específicas instituídas para além do código legal vigente e acatadas, de maneira R. Fac. Dir. UFG, V. 37, n. 02, p. 196 - 234, jul. / dez. 2013 
consensual, nos meandros das relações de vários grupos familiares"; b) tanto podem expressar um "acesso estável à terra”, em decorrência de colonização antiga, quanto "formas relativamente transitórias", decorrentes de ocupação recente; c) a atualização dessas normas ocorre em territórios próprios, "cujas delimitações são socialmente reconhecidas, inclusive pelos circundantes"; d) a territorialidade específica é um fator de identificação, defesa de direitos, luta, coesão e força; e) laços solidários e de ajuda mútua "informam um conjunto de regras firmadas sobre uma base física comum, essencial e inalienável, não obstante disposições sucessórias, porventura existentes."

A Lei $\mathrm{n}^{\circ} 601$, de 1850, ao disciplinar o novo regime jurídico de terras, contudo, não reconheceu a ocupação indígena nem permitiu que camponeses adquirissem terras necessárias para sua sobrevivência, e, portanto, somente era possível a aquisição de terras por meio da compra, evitando que estas fossem adquiridas por índios ou pelos negros que estavam sendo libertos (ATAIIDE JR, 2006, p. 174-177), o que ocasionou um sistema informal de registros, simultâneo à grilagem e à concentração de terras em mãos de poucos proprietários. É o momento também que se estabelece o conceito de "terras devolutas" que vigorará até o advento do Decretolei $\mathrm{n}^{\circ} 9.760 / 46 .{ }^{10}$

E aqui evidentes alguns paradoxos da Lei de Terras: a) erige-se um aparato regulatório para "proteger a propriedade privada da terra contra as ocupações, quando até essa data (a partir de 1822) a posse era norma para consegui-la" (MARICATO, 2000, p. 145-150); b) um constrangimento para o reconhecimento de posses, ao mesmo tempo em que inúmeros imóveis foram recadastrados com registros em cartórios, devolvidos, novamente reconhecidos e titulados, comportando em seus domínios inúmeras situações de posse; c) a criação, para fins de demarcação de "terras devolutas", de arquivos, registros e organismos ineficientes sucessivamente substituídos, de tal forma poder-se afirmar que "até praticamente nossos dias, as terras devolutas têm sido privatizadas, tirando proveito de uma situação de fragilidade na demarcação da propriedade de terra no Brasil durante mais de quatro séculos". Mais que isto: os governos provinciais vão declarando 
extintos os antigos aldeamentos indígenas e incorporando tais terras para os municípios em formação. ${ }^{11}$

Não é coincidência, pois, que a transferência das terras para as elites locais coincida com um período de trinta anos de várias guerras camponesas, das quais a Canudos e Contestado são "marcos na longa e persistente violência da ocupação das fronteiras agrícolas brasileiras." (MARÉS, 2006, p. 158)

Assim, vão ser encontradas, ocupadas por comunidades predominante negras ${ }^{12}$, "terras de índios" (entregues formalmente a indígenas ou seus descendentes, sob a forma de doação ou concessão, em função de serviços prestados ao Estado, como abertura de estradas e colaboração com expedições militares de desbravamento) (ANDRADE, 2008), "terras de pretos" (domínios doados, entregues ou adquiridos, por famílias de ex-escravos, ou concessões a essas famílias mediante prestação de serviços guerreiros), "terras de santo" (as extensões de terras exploradas por ordens religiosas abandonadas ou entregues para determinados moradores, recebendo a denominação da santidade padroeira, p. ex, Santa Teresa), "terras de herança" (domínios titulados, tornados espólios, que permanecem indivisos, sem a formalização da partilha) e tantas outras denominações. ${ }^{13}$

Vale dizer: tais sistemas de "usufruto comum", por "colidirem frontalmente com as disposições jurídicas vigentes e com o senso comum de interpretações oficiosas e já cristalizadas”, não foram- nem tem sido, no geral - objeto de inventariamento e mesmo de estudo sistemático pelas disciplinas jurídicas.

Disso se seguem alguns pontos interessantes para a análise.

Primeiro: a pouco admitida intrincada relação entre "legalidade" e "ilegalidade" no âmbito da questão fundiária brasileira. Como bem observa James Holston, a elite rural "controlou a distribuição da terra criando tamanha complexidade na legislação sobre as sesmarias que somente aqueles que já estavam no poder podiam dominá-la": ao contrário do comumente afirmado, "a estratégia não foi a de negar a lei", mas sim "de criar um excesso de leis, de modo a aplicar 
minuciosamente o fundamento jurídico teuto-romano segundo o qual 'a lei não tem lacunas'”. (HOLSTON, 1993)

Saliente-se, ainda, que, desde o Império até a Primeira República, a interpretação da maior parte dos juristas não foi de que as terras devolutas pertenciam ao domínio público do Estado, mas sim faziam parte dos bens patrimoniais, podendo ser "objeto de hipoteca, compra, venda, permuta ou qualquer negócio jurídico de direito privado.” (SILVA, 2008, p. 343-347) Dentro desta histórica dualidade legalidade/ilegalidade no tratamento da territorialização, que marca a legislação desde a Lei de Terras de 1850, é que o próprio zoneamento urbano serviu, em boa parte, para fins de interesses econômico-políticos do mercado imobiliário, inclusive porque os diferentes "graus de ilegalidade" fazem com que algumas práticas "sejam mais toleradas e mesmo mais justificadas do que outras, que provocam a ação repressiva do Estado"14

É que, findo o sistema de doações de terras por "sesmarias" em 1822 (em que primeiro se recebia o título, para depois trabalhar a terra), estas não eram mais concedidas e tampouco existia uma lei disciplinando a questão, com o que quatro situações estavam configuradas (SODERO, 1990, p. 42-48): a) sesmarias concedidas e integralmente confirmadas, com o atendimento de todas as exigências e, pois, o proprietário tinha o domínio sobre a gleba; b) sesmarias simplesmente concedidas, faltando cumprimento de alguma exigência, com o que inexistia domínio, mas simples posse; c) glebas ocupadas por simples posse, sem qualquer título; d) terras sem ocupação, não concedidas ou já revertidas para o Poder Público por não cumprimento das exigências.

No intervalo de tempo entre o fim do regime de sesmarias e Lei de Terras, passa a vigorar o regime de posses e existem inúmeros projetos legislativos que procuram valorizar benfeitorias nas terras, a combinação de reforma agrária com abolição de escravatura, a reversão de sesmarias não efetivamente ocupadas, etc, e, desta forma, "caso a posse tivesse sido regulamentada e o cultivo e uso efetivo das terras tivesse passado a ser critério para legitimação de terras no Brasil', por exemplo, os aquilombados, no período pós-abolição, poderiam "ter se beneficiado 
desse regime de terras.” (GOMES, 2010, p. 191-192) Como recorda Jacques Alfonsin, os direitos humanos fundamentais à alimentação e à moradia, "independentemente de a pessoa ter, ou não, propriedade, têm sido, historicamente, muito menos valorizados como fim natural e jurídico da terra, do que o apetite do mercado.” (ALFONSIN, 2003, p. 195-196.) E, por isso, o descumprimento da função social é, no seu entender, hipótese de "onerosidade excessiva” ou de "abuso do direito”, a pesar sobre toda a sociedade. (Idem, p. 199-200)

Segundo: a excessiva preocupação com o formalismo e os distintos graus de "legalidade" obscurece o estudo destas situações de evidente pluralismo jurídico. Sally Engle Merry, revisando a literatura sobre o tema, destacava a existência de dois períodos analíticos: a) o pluralismo jurídico clássico, em que os estudos das sociedades coloniais verificavam a autonomia e interseção entre duas ordens jurídicas distintas (colonizador e colonizado), sendo explícita a vigência, no mesmo espaço geopolítico, do Direito de Estado do colonizador e dos direitos tradicionais (veja-se a preservação do direito de família para comunidades islâmicas ou hinduístas pelo Império britânico); b) o novo pluralismo jurídico, aplicado a sociedades urbanas industrializadas, em que a perspectiva já não é de duas ordens separadas e culturalmente diferentes, mas sim de uma complexa relação de ordens jurídicas distintas.

Para ela, o estudo do pluralismo jurídico amplia o marco de investigação de cinco formas (MERRY, 2007, p. 95-125): a) afasta-se da ideologia do centralismo jurídico e que toda ordenação jurídica se baseia no direito estatal, mostrando formas antagonistas, conflitivas e contraditórias que estão fora e além do direito estatal; b) exige passar de uma concepção essencialista para uma histórica do direito; c) examina a "natureza cultural ou ideológica do direito e dos sistemas de ordenação normativa", de tal forma que o direito passa a ser visto como "um sistema de pensamento através do qual certas formas de relação chegam a ver-se como naturais de fato"; d) determina a mudança de ênfase para situação em que não existem conflitos, que são a regra, e não a exceção; e) contribui a expandir a análise para as relações dialéticas entre ordens normativas, permitindo verificar limites de dominação e possibilidades de resistência. 15 
Como já observava Roberto Lyra Filho, “o Direito, que passa da ilegalidade para legalidade, já é um fenômeno jurídico, antes que o Estado o reconheça; e permanece jurídico, mesmo que o Estado retarde ou negue tal reconhecimento" e afirmava:

De outra forma, não poderíamos conceber o Direito de resistência à opressão tirânica; os Direitos Humanos em geral, quando postergados; o Direito Internacional, enquanto, por exemplo, define e sanciona, com medidas vária, os crimes dos Estados, por seus agentes, como o genocídio, em qualquer modalidade; o Direito dos povos à libertação nacional contra o invasor e colonizador em seu território estabelecidos e assim por diante. (1982, p. 34)

Terceiro: a invisibilidade do pluralismo jurídico é a outra face de um profundo processo de “colonialismo interno." O conceito, desenvolvido quase que simultaneamente por Pablo González Casanova e Rodolfo Stavenhagen, não tem sido muito utilizado no meio jurídico.

Para o primeiro autor, analisando os povos indígenas, a ideologia liberal, que considera todos iguais perante a lei, foi um avanço em relação às ideias racistas prevalecentes na Colônia, e o mesmo pode se dizer dos estudos antropológicos. Mas salienta que isso não explica a questão em termos essenciais, e - no que pode ser aplicado, sem dúvida, a quilombolas, ciganos e populações tradicionais- afirma categoricamente (CASANOVA, 1967, p. 91-92):16

O problema indigena é essencialmente um problema de colonialismo interno. As comunidades indígenas são nossas colônias internas. A comunidade indígena é uma colônia no interior dos limites nacionais. A comunidade indigena tem as características da sociedade colonizada. Mas este fato não apareceu com suficiente profundidade ante a consciência nacional. (...) Acostumados a pensar em colonialismo como um fenômeno internacional, não temos pensado em nosso próprio colonialismo.

Daí porque Rodolfo Stavenhagen, na mesma época, rejeitava como uma das “sete teses equivocadas sobre América Latina” a de que seriam "sociedades duais": a) 
uma "arcaica", com relações de tipo essencialmente familiar e pessoal, com estratificação rígida e por normas que valorizam o "status quo"; b) outra, "moderna", com fins racionais e utilitários, com estratificação pouco rígida, orientada para o progresso, inovações e racionalidade econômica. Para ele, o tipo de relações que "se estabeleceu entre metrópole colonial e suas colônias se repetiu dentro dos próprios países coloniais", sendo importante as "relações que existem entre este 'dois mundos", de tal forma que as denominadas "regiões subdesenvolvidas" faziam as vezes de "colônias internas".

Melhor seria tratar a questão, pois, como de "colonialismo interno" e, portanto: a) os dois polos são o "resultado de um único processo histórico"; b) as relações mútuas que conservam entre si as regiões e os grupos "representam o funcionamento de uma só sociedade global, da qual ambos são partes integrantes." 17

Nesta ótica, as "comunidades tradicionais"- das quais os quilombolas, faxinalenses, as quebradeiras de coco de babaçu e os ribeirinhos são exemplos - não são representantes de um passado, nem "vestigio", nem meros "remanescentes": são parte da estrutura agrária do presente e tão modernas e contemporâneas quanto os agricultores que utilizam transgênicos ou os pesquisadores de células-tronco.

Ou dito nos termos da análise de Aníbal Quijano, que vai romper esta “perspectiva eurocêntrica sobre o Estado-Nação”, a modernidade não está dissociada da colonialidade, pois esta "é um dos elementos constitutivos e específicos do padrão mundial do poder capitalista", sustentada "na classificação racial/étnica da população do mundo como pedra angular do referido padrão de poder”. (QUIJANO, 2010, p. 84-85)

Para ele, os indivíduos classificam-se e são classificados segundo três linhas diferentes (trabalho, raça, gênero), articuladas em torno de dois eixos centrais: a) o controle de produção de recursos de sobrevivência social, que implica o "controle da força de trabalho, dos recursos e produtos de trabalho", incluindo "recursos 
naturais" e se institucionaliza como propriedade; b) controle da reprodução biológica da espécie, que implica o controle do sexo, do prazer e da descendência, em função da "propriedade". A "raça", por sua vez, foi incorporada ao capitalismo eurocentrado em função de ambos os eixos. Ou seja, tanto a classificação social é heterogênea, descontínua e conflituosa, quanto suas articulações. (Idem, p. 113-114)

A colonialidade do poder, segundo ele, é "o eixo que as articula numa estrutura comum do poder". Não é à toa, pois, que os setores "modernos" da agricultura possam conviver com a manutenção de distintas formas de trabalho escravo ou forçado e que haja tanta resistência para entender, nessa hipótese, de violação à função social da propriedade. Ou que as empresas de luxo vivam às expensas do trabalho de imigrantes ilegais e que tenha havido tanta resistência para equiparação de direitos trabalhistas ao "trabalho doméstico", onde se cruzam as discriminações de gênero, raça e classe, um resquício escravocrata, preservado na própria arquitetura do quarto de empregada, com pouco espaço e ventilação, reproduzindo o espaço da senzala. (CACCIAMALI, 2008, p. 253-267)

\section{As várias posses e propriedades: alargando os conceitos a partir de territorialidades específicas.}

Paolo Grossi destacou o pesado condicionamento monocultural para apreciação da questão da propriedade, esquecendo-se que para culturas africanas, asiáticas e americanas "não é tanto a terra que pertence ao homem, mas antes o homem à terra, onde a apropriação individual parece invenção desconhecida ou disposição marginal.” (GROSSI, 2006, p. 07) E mesmo no quadrante europeu, o horizonte é "demasiadamente vinculado à oficialidade dominante", havendo todo um “complexo de realidades sepultadas", de "organização comunitária de uma terra, nas quais não é somente o espírito individualista que falta, mas até o mesmo o próprio espírito proprietário." Essa "propriedade coletiva” tem uma plataforma comum:

de ser garantia de sobrevivência para os membros de uma comunidade plurifamiliar, de ter um valor e uma função essencialmente alimentares, em que o conteúdo fundamental é um gozo condicionado do bem, com um indiscutível primado do objetivo sobre o subjetivo. (...) Essa assim chamada 'propriedade 
coletiva' é uma propriedade? Temos certeza de usar legitimamente um tal termo para a sua descrição? (Idem, p. 08)

Como historiador do direito, salienta que o regime medieval das propriedades até o século XIX, na Europa - "os dominia medievais" - pouco tem a compartilhar com a propriedade moderna, mas existe, todavia, um continuum, ainda quando o dominium "não cai do sujeito sobre a coisa, mas nasce da coisa, e a sua consequente dessacralização" (Idem, p. 57). É, portanto, um "processo de renovação que leva cinco séculos", construindo um "sistema objetivo de propriedades", a partir das "coisas e sobre as coisas, reprodutor fiel da trama complexa", ao passo que ordem nascente "se volta em direção oposta", em uma "busca desesperada de autonomia" (Idem, p. 61-64)

Desta forma, o autor salienta que a propriedade medieval é uma entidade complexa e composta:

Tantos poderes autônomos e imediatos sobre a coisa, diversos em qualidade segundo as dimensões da coisa que os provocou e legitimou, cada um dos quais encarna um conteúdo proprietário, um domínio (o útil e o direto), e cujo feixe compreensivo reunido por acaso em um só sujeito pode fazer dele o titular da propriedade sobre a coisa. (...) essa propriedade não é uma realidade monolítica, a sua unidade é ocasional e precária, e cada fração leva em si a tensão a tornar-se autônoma e a força para realizar o desmembramento; [...] frequentemente, mesmo simples atos de administração do proprietário ( por exemplo, em certas condições, até um contrato agrário) podem levar à divisão em muitas frações da unidade composta.( Idem, p. 66)

Daí destacar que o medieval da propriedade "consistia na organização da sua complexidade e na valorização da sua natureza composta", enquanto o "moderno da propriedade está todo no descobrimento de sua simplicidade". (Idem, p. 67) A convivência destas duas realidades antropológicas distintas faz, com que, paradoxalmente, "a ordem fundiária de um certo momento histórico é muito mais aquilo que circula invisível no ar daquele momento, do que aquilo que resulta inscrito entre os sinais sensiveis da paisagem agrária.” (Idem, p. 24) 
Assim, a noção liberal clássica de propriedade é "insuficiente para descrever e abordar as diferentes formas de acesso à terra de fato" e não "permite incorporar a diversidade de formas por meio das quais a população rural e urbana marginalizada se relaciona com a terra" (GARCÍA, 2001, p. 105), tais como a colonização sobre áreas de reserva florestal ou a informalidade dos títulos de posse.

Para Helena Alviar García, "se bem a noção de propriedade em matéria agrária tem particularidades que devem ser anotadas, a noção de propriedade clássica segue coexistindo com este regime especial" e, por isso, "as limitações e restrições próprias da propriedade agrária geram contradições e inconsistências no momento de adjudicar a propriedade”. Assim, apesar das limitações que impedem o direito de propriedade absoluto, "nem por isso deixa de ser a categoria principal a partir da qual opera toda a política do setor": daí porque é mais provável que o proprietário consiga acesso ao sistema financeiro que o possuidor que explora a terra ou que goze de proteção, como no caso colombiano, por deslocamento.

O que a questão quilombola em especial - e, eventualmente, o acesso à terra por outras "populações tradicionais"- poderia(m) ensejar para o direito agrário?

Primeiro: a necessidade do efetivo desgarramento do direito agrário ou destas questões agrárias coletivas do tradicional direito civil, envolvendo-se com novas questões de direito internacional de direitos humanos. Assim, por exemplo, é pacífico o entendimento da Corte Interamericana que, na previsão do art. 21 da Convenção Americana de Direitos Humanos ("toda pessoa tem direito ao uso e gozo dos seus bens", e "a lei pode subordinar esse uso e gozo ao interesse social”), "tanto a propriedade privada dos particulares como a propriedade comunitária dos membros das comunidades indígenas têm a proteção convencional” 18 Para tanto, ela tem considerado " a especial relação que tais povos guardam com o território e a necessidade da preservação deste para fins de sobrevivência física e cultural" (religião, práticas agrícolas, caça, pesca e modos de vida das respectivas comunidades). Também ficaram incluídos os "povos tribais", de que trata a Convenção $\mathrm{n}^{\circ} 169$ da OIT ${ }^{19}$, em especial os descendentes de escravos, ainda que os países não tivessem aderido à referida Convenção, pois entendeu que a proteção 
decorria da análise conjunta da Convenção com os Pactos Internacionais das Nações Unidas sobre Direitos Civis e Políticos e sobre Direitos Econômicos, Sociais e Culturais, que garantem direitos fundamentais (como o direito de propriedade) a todos os povos (art. $1^{\circ}$ dos dois Pactos).

Segundo: estas questões de direito internacional obrigam os governos a respeitar a "importância especial para as culturas e valores espirituais dos povos interessados, sua relação com as terras ou territórios, ou ambos, conforme o caso, que ocupam ou usam para outros fins e, particularmente, os aspectos coletivos dessa relação", na forma do art. 13 da Convenção 169 da OIT. Recentemente, isto ficou claramente demonstrado no relato de Sabino Gualinga, ao declarar que a "Sarayaku é uma terra viva, é uma selva vivente", existindo "árvores e plantas medicinais, e outros tipos de seres", nestes termos: 20

En el subsuelo, ucupacha, igual que aquí, habita gente. Hay pueblos bonitos que están allá abajo, hay árboles, lagunas y montañas. Algunas veces se escuchan puertas cerrarse en las montañas, esa es la presencia de los hombres que habitan ahí... El caipacha es donde vivimos. En el jahuapacha vive el poderoso, antiguo sabio. Ahí todo es plano, es hermoso... No sé cuantos pachas hay arriba, donde están las nubes es un pacha, donde está la luna y las estrellas es otro pacha, más arriba de eso hay otro pacha donde hay unos caminos hechos de oro, después está otro pacha donde he llegado que es un planeta de flores donde vi un hermoso picaflor que estaba tomando la miel de las flores. Hasta ahí he llegado, no he podido ir más allá. Todos los antiguos sabios han estudiado para tratar de llegar al jahuapacha. Conocemos que hay el dios ahí, pero no hemos llegado hasta allá.

Em sentido similar, foi o depoimento do Chefe Wazen Edwards, da comunidade negra Saramaka:21

El bosque es como nuestro mercado local; allí obtenemos nuestras medicinas, nuestras plantas medicinales. Allí cazamos para tener carne que comer. El bosque constituye verdaderamente nuestra vida entera. Cuando nuestros ancestros se escaparon al bosque, no llevaban nada con ellos. Aprendieron cómo sobrevivir, qué plantas comer, cómo manejar sus necesidades de subsistencia una vez que llegaron al bosque. Es toda nuestra forma de vida. 
O título de propriedade, nestas hipóteses, segundo já decidiu a Corte Interamericana, se justifica como garantia de "certeza jurídica", para fins de "uso e gozo permanente da terra." 22

Terceiro: visto a partir desta especial relação com a terra, tanto eventual "conceito" de "posse" quanto de "propriedade" implicam uma multiplicidade de direitos, que vão além dos clássicos "jus utendi", "jus fruendi” e "jus abutendi”, para enfeixar um grupo de direitos culturais, econômicos e sociais, tais como: a) reprodução social, cultural e espiritual da comunidade; b) o respeito à diversidade étnica, religiosa e cultural; c) a pluralidade socioambiental, econômica e cultural dessas comunidades (incluídas as relações familiares e de parentesco); d) o direito à memória cultural e à prevenção do epistemicídio; e) o direito de autoatribuição, de "nomeação" dos lugares, de definição de seus "usos legítimos", de vinculação da existência à trajetória coletiva; f) o direito à alimentação, visto não mais no sentido assistencialista, mas como direito à segurança e soberania alimentar. ${ }^{23}$

Tanto posse quanto propriedade passam a ser vistas, nesse sentido, como "cluster of rights", um verdadeiro feixe de direitos entrelaçados, indivisiveis e interdependentes, numa renovação também da teoria de direitos humanos e muito além do conceito de "função social" ou "função ecológica" da propriedade.

Quarto: como bem destaca Boaventura Santos, a temporalidade das lutas quilombolas é distinta, por exemplo, das lutas de indígenas e de sem terras: a luta pela terra está ligada ao tempo largo da escravidão, ao passo que no segundo caso, à colonização e ao esbulho dos territórios pelos conquistadores e na última, ao momento atual de concentração fundiária. (SANTOS, 2007, p. 28)

Mais que isto: as formas de apropriação/utilização do território implicam desafios e estratégias distintas de resistência. As terras indígenas, sendo propriedade da União, ainda que com usufruto permanente das comunidades, ensejam um processo de, por um lado, tentativa de privatização de espaços públicos 
e, portanto, de manutenção de relações coloniais e de padrões racistas de usurpação de terras.

Por sua vez, as terras quilombolas, constituindo propriedade inalienável, mas de apropriação coletiva, não necessariamente com caráter público, implicam uma resistência ao processo de mercantilização extremo da terra, de descaracterização dos conhecimentos tradicionais e de também continuação de racismo epistêmico, como resquício da escravidão. ${ }^{24}$

As demais formas de "uso comum" nem sempre caracterizam titulação coletiva ou mesmo caráter público, podendo consistir em simples acesso à propriedade pública ou privada, sem qualquer titulação. Implica formas de resistência distintas, embora, de uma forma ou de outra, contra a privatização da terra. É o caso das comunidades de "fundo de pasto", que adotam um modo particular de uso comum do território ("terras soltas ou abertas"), onde a criação de gado vive solta, sem cercamento, as aguadas são compartilhadas e somente os roçados são mantidos com cercas. Se, no primeiro momento, o processo de reconhecimento jurídico significou "vitória contra os interesses que queriam ser apropriar dessas terras, com o passar do tempo, tem se mostrado inadequado ao modo de vida das comunidades", porque as terras "foram convertidas em propriedade privada da família ou de uma associação", fazendo com que o uso comum, que era "regido por normas internas dos grupos, passa a ser regido pelas regras do mercado imobiliário e do direito civil". Em suma: "o processo de regularização enfatizou a necessidade de terras para a criação animal", deixando de observar o "processo de territorialização que culminou na formação de sua territorialidade específica." (CARVALHO, 2011, p. 167-176)

Destaque-se, por exemplo, a questão dos "faxinalenses", caracterizados pelos "criadouros comuns, áreas de uso comunitário para criação animal à solta, relações de trabalhos comunitárias e familiares e o uso diferenciado dos recursos territoriais" associado à reprodução da vida. Sua luta tem sido não tanto pelo reconhecimento das características físicas do faxinal ou do sistema de produção vigente, mas sim "da identidade coletiva e da reprodução de seu modo de vida tradicional". Aqui, é o 
território da identidade associada aos movimentos sociais, à disputa de modos diferenciados de reprodução de vida, de outro tipo de desenvolvimento, de "viver bem" e, desta forma, não é uma luta para "fixidez" do lugar, mas sim para a própria definição da direção e do ritmo da sua mudança. (ROCHA, 2003, p. 167-ss)

Desta forma, a "questão da terra combina a questão da justiça social com a questão da justiça étnico-cultural e da justiça racial", ou seja, "a luta contra a desigualdade social vai de par com o reconhecimento da interculturalidade e da dívida histórica que o colonialismo criou nesse país.” (SANTOS, 2007, p. 103-104) Como destaca Vânia Moreira, as disputas pela terra na "questão quilombola” são também "disputas em torno da compreensão que a sociedade deve ter a respeito da história (passado), do direito e da cidadania (presente-futuro) e de conceitos fabricados nas oficinas da história e da antropologia (ciência)" (MOREIRA, 2009, p. 247-248)

Mas também como "proposta alternativa de racionalidade", de efetiva "justiça cognitiva", não como uma "volta atrás", pois o "passado pode ser uma vivência do presente, não sua nostalgia, não a inocência perdida, mas sim uma sabedoria integrada." (QUIJANO, 1988, p. 21-ss)

Quinto: a necessidade de repensar um ponto que a Corte Interamericana vem destacando ao apreciar o art. 25 da Convenção ("toda pessoa tem direito a um recurso simples e rápido ou a qualquer outro recurso efetivo, perante os juízes ou tribunais competentes") e que vem expresso como "proteção judicial eficiente." Segundo ela, ocorre violação ao referido artigo "quando o sistema judicial do Estado não está desenhado adequadamente para reparar as violações aos direitos de propriedade coletiva dos povos indígenas e tribais”, ou seja, quando os recursos jurídicos existentes não são adequados e eficazes. ${ }^{25}$ Recorde-se, também, "a inexistência de um recurso efetivo contra as violações aos direitos reconhecidos pela Convenção" constitui uma transgressão da mesma, não bastando que esteja previsto na Constituição ou na lei ou que "seja formalmente admissível, mas sim que seja realmente idôneo para estabelecer se tenha incorrido numa violação aos direitos humanos e prover o necessário para remediá-la” 26 
E, dentro desta lógica, é imperioso destacar que os direitos coletivos que não sejam "o conjunto ou soma de direitos individuais" são tidos como "invisíveis" e como direitos individuais vem sendo tratados. Como destaca Carlos Marés, direitos como de indígenas, quilombolas e populações tradicionais, enquanto direitos coletivos, são "invisíveis ainda hoje" e "cada vez que são propostos ou reivindicados, é desqualificado o seu sujeito: o povo indígena, se reivindica um direito coletivo, deve fazê-lo como pessoa jurídica, o MST só pode ser visto como reivindicante de direitos individuais à propriedade de lotes de terra", do que segue "a extrema dificuldade do Poder Judiciário em entender ou acatar o direito coletivo reivindicado". ${ }^{27}$

Tal questão, como destacado, foi enfrentada no Caso Saramaka vs. Suriname, ficando assentado que: a) o Estado havia violado tal direito, ao não reconhecer a possibilidade de personalidade jurídica à comunidade (parágrafo 171); b) o Código Civil daquele país era inadequado porque "somente estava disponivel para pessoas individuais que reclamam seus direitos individuais à propriedade privada" (parágrafo 179); c) a comunidade, "como entidade coletiva cuja personalidade jurídica não está reconhecida pelo Estado, não podia utilizar o recurso" nessa qualidade "para afirmar o direito à propriedade comunal de seus integrantes." (parágrafo 179).

Nesse sentido, é que deve ser repensado se os institutos possessórios, típicos de direito civil, são adequados e suficientes tanto para a proteção dos direitos das comunidades indígenas, em que o próprio STF entendeu tratar-se de "heterodoxo instituto de direito constitucional", quanto para os direitos quilombolas, previstos no art. 68 do $\mathrm{ADCT}^{28}$, e também das demais populações tradicionais.

\section{Princípio da não discriminação e a igualdade}

Ao menos 15 países latino-americanos reconhecem tipo de direito coletivo, legal ou constitucionalmente, a povos indígenas, mas somente Bolívia, Brasil, Colômbia, Equador, Guatemala, Honduras e Nicarágua estendem alguma forma de proteção a afrodescendentes. 
Ariel Dulitzky questiona qual será a orientação da Corte Interamericana em relação aos países: a) "onde a propriedade coletiva é reconhecida a povos indígenas, mas não a afrodescendentes"; b) "onde as regulações constitucionais de direitos coletivos para indígenas são maiores que os direitos coletivos reconhecidos aos afros." (DULITZKY, 2010, p. 30)

Analisando a jurisprudência da Corte Interamericana, ele destacou algumas dificuldades neste sentido (Idem, p. 13-48): a) a aproximação cultural opta por localizar geograficamente somente as comunidades rurais que podem demonstrar sua "indigeneidade" ou "africanidade" de uma maneira cultural determinada, podendo produzir efeitos no interior do movimento negro, obrigando a ressaltar a identidade cultural antes que a racial ${ }^{29}$; b) deve ser avaliada, durante o processo de litígio, a possibilidade de ocorrência de conflitos intra e inter comunitários que possam emergir; c) a Corte deveria ser mais casuística em suas decisões, evitando "repetir mecanicamente prévias decisões que, não necessariamente, se adéquam às particularidades de cada caso ou ao contexto legal, político, social ou econômico no qual se produzem as diferentes reclamações"; d) a falta de proteção efetiva dos territórios indígenas e negros não pode e não deve ser considerada, exclusivamente, como um problema de "falta de reconhecimento de suas particularidades distintivas, mas sim de discriminação e marginalidade a que os Estados os submetem". Para ele, uma aproximação com a perspectiva da igualdade e não discriminação "permitiria considerar as desigualdades e racismo estrutural de que são vítimas indígenas e afro-descendentes."

Em relação à questão da igualdade e da não discriminação, que pontos poderiam ser destacados em relação às "comunidades tradicionais", em especial as quilombolas, para a renovação do Direito Agrário?

Primeiro: Roger Raupp Rios, analisando a jurisprudência do STF sobre o princípio da igualdade, salienta que, entre 1950 e 1988, "predominaram a condescendência diante de realidades discriminatórias e a desoneração argumentativa perante tratamentos díspares”, versando sobre questões administrativas e processuais, para, somente a partir de 1988, um "maior rigor em 
face de diferenciações e a emergência do conteúdo antidiscriminatório do princípio da igualdade." (RIOS, 2011, p. 289-339) Nesse sentido, a jurisprudência do STF vem avançando no reconhecimento de uma "igualdade substancial", de que são exemplos os julgamentos envolvendo a constitucionalidade das ações afirmativas nas universidades e o PROUNI, mas ainda não avançou na relação entre princípio da igualdade e reconhecimento de direitos culturais e territórios, para fins de discriminação no acesso à terra.

Segundo: porque estes processos envolvendo comunidades quilombolas dizem respeito também ao próprio "status jurídico" da oralidade, dos testemunhos orais e da história oral como provas dentro de um processo judicial, que está acostumado com a escritura, como forma de reprodução de conhecimento dito científico. São depoimentos, lembranças, relatos e vivências colocados dentro de processos administrativos e judiciais a justificar a territorialidade, a ancestralidade, a convivência em comunidade, os laços de parentesco, as formas de religiosidade, as disposições de utilização da propriedade. Isto implica, também, a produção da visibilidade das manifestações destas comunidades e de um processo de justiça cognitiva, reavaliando a ciência como única forma de conhecimento. ${ }^{30}$ Ademais, as próprias comunidades rompem o padrão eurocentrado: a resistência negra não somente preservou saberes africanos e afro-brasileiros, mas desenvolveu um sistema de sabedoria, história, memória da opressão, experiência vivida, aprendizado. (COSTA, 2010)

Disso se segue, também, que a avaliação das provas deve ser realizada considerando o princípio da igualdade. Dessa forma, o juízo de proporcionalidade, aqui, exige que sempre se busquem, "para alcançar os benefícios gerais necessários, as alternativas menos onerosas do ponto de vista do dever de superar a situação de subordinação do grupo desavantajado", de tal forma que não havendo esta alternativa, necessário verificar "se o propalado benefício geral é mais importante para a sociedade do que a superação da situação da subordinação". (RIOS, 2004, p. 36) 
Veja-se, por exemplo, o julgamento envolvendo a definição da terra indígena urbana "Morro do Osso", em Porto Alegre/RS, em que o xamã da comunidade afirmava a existência de um cemitério kaingang no local. O TRF da $4^{\mathrm{a}}$ Região proferiu decisão no sentido de que enquanto não se realizam as pesquisas processuais e antropológicas, "não há justificativa para que a comunidade indígena seja privada de sua posse local, sendo relegada a aceitar sofregamente os ônus das nossas fórmulas processuais", de tal forma que não são as comunidades que devem “aguardar nossos processos de ocupação de suas terras”. Antes pelo contrário: nós que devemos "aguardar o resultado de nossos próprios processos administrativos e judiciais para afirmar que as comunidades não apresentam os direitos que alegam" 31

Mas a situação reforça a necessidade de o Poder Judiciário desenvolver mecanismos, práticas e sensibilidades para lidar com a história oral e laudos antropológicos. Inclusive porque, em relação a estas "comunidades tradicionais", a visibilidade somente pode ser reconhecida, na maior parte das vezes, por meio destas provas e não de documentação ou início de "prova material". Uma verdadeira e urgente necessidade de reapreciar a visão processualística e reverter a "invisibilidade" destas comunidades.

Terceiro: a questão da conveniência, dadas as peculiaridades já narradas em relação a tais comunidades tradicionais, indigenas ou quilombolas, da existência de um "tradutor cultural", um profissional que não se confunde nem como o intérprete nem necessariamente com o perito, podendo ser um antropólogo (ou de qualquer das ciências sociais), mas que seja "capaz de fazer compreender ao juiz e às demais partes do processo o contexto sócio-político e cultural daquele grupo", um responsável, pois, pelo diálogo intercultural, tornando mutuamente inteligíveis as demandas e especificidades, evitando que o "sistema judicial ignore a diversidade e aplique o direito sempre do ponto de vista étnico dominante". ${ }^{2}$ Ora, se a Constituição assegura às minorias étnicas o exercício de seus direitos sem a necessidade de serem assimiladas, devem, consequentemente, ser "adotadas medidas para garantir que os membros desses povos possam compreender e se fazer compreender em procedimentos legais, facilitando para eles, se for R. Fac. Dir. UFG, V. 37, n. 02, p. 196 - 234, jul. / dez. 2013 
necessário, intérpretes ou outros meios eficazes", conforme preceitua o art. 12 da Convenção 169-OIT. À falta de disciplina específica do direito processual civil, nada impede seja utilizada a previsão da convenção internacional, que tem, na atual jurisprudência, status supralegal. Ou seja, uma perspectiva intercultural de tradução de realidades não eurocentradas, a necessidade de um "princípio da proporcionalidade extensivo".

Quarto: a necessidade de maior conhecimento de outras experiências jurisprudenciais do continente. A jurisprudência colombiana, em decorrência de um amplo reconhecimento da diversidade cultural, a partir da leitura da Constituição de 1991, vem desenvolvendo o conceito de "igualdade extensiva". Segundo a Corte Constitucional da Colômbia ${ }^{33}$, o princípio da igualdade, na forma do art. 13, implica quatro mandatos:

(i) um mandato de trato idêntico a destinatários que se encontrem em circunstâncias idênticas, (ii) um mandato de trato inteiramente diferenciado a destinatários cujas situações não compartem nenhum elemento em comum, (iii) um mandato de trato paritário a destinatários cujas situações apresentem similitudes e diferenças, (iv) um mandato de trato diferenciado a destinatários que se encontrem também em uma posição em parte similar e em parte diversa, mas em cujo caso as diferenças sejam mais relevantes que as similitudes.

Desta forma, tem-se entendido que a "omissão legislativa relativa de caráter discriminatório", produzida pela não inclusão de todos supostamente iguais aos regulados pela lei, significa, no geral, que tais disposições não são inconstitucionais pelo que, em si, dispõem, mas sim "por não fazer extensivas essas disposições a outros supostos de fato iguais aos regulados", fazendo com que a Corte profira uma sentença integradora, "que faz extensivos os efeitos da regulação legal aos fatos não contemplados pela lei". ${ }^{34}$

Na doutrina nacional, Jayme Weingartner Neto tem defendido que se trata, pois, de estender a todos os grupos um direito que já se encontra concretizado, à falta de fundamento racional ou material que determine tratamento diferenciado: extensão, por igualdade, do regime mais favorável já disciplinado. (WEINGARTNER 
NETO, 2007, p. 204) E salienta que, se a religião católica tem um regime mais favorável já legislado, isso não impede sua extensão às religiões afro-brasileiras, por exemplo, devendo-se considerar a situação da confissão religiosa, da orientação sexual ou do grupo mais favorecido como "patamar normal de referência" e, desta forma, "qualquer desvio de tratamento das minorias, em relação à maioria, é concebido a priori como restrição ao direito de igualdade." (MACHADO, 1996, p. 302)

Recentemente, a Corte Constitucional colombiana ${ }^{35}$, apreciando a Lei $\mathrm{n}^{\circ}$ $1.537 / 2012$, que estabelece normas para promover desenvolvimento urbano e o acesso à habitação digna, decidiu que: a) o legislador tinha o dever constitucional de incluir tanto o povo Rrom ou gitano como a comunidade de raizales do arquipélago de San Andrés, "dentro dos critérios de priorização e focalização das famílias potencialmente elegiveis e merecedoras de subsídio de habitação em espécie", incorrendo em violação ao direito à igualdade de trato entre todas as culturas do país; b) a qualidade de minoria étnica constitui um critério de "maior priorização e focalização" para fazer-se beneficiário de habitação; c) rechaçou critérios de hierarquia entre grupos étnicos, garantindo a "simetria entre os direitos dos povos Rrom ou gitanos, as comunidades raizales do arquipélago de San Andrés e os reconhecidos aos demais grupos étnicos e culturais do país"; d) a não previsão específica para os grupos que ajuizaram a ação representa "omissão legislativa relativa por existência de tratamento discriminatório ao interior de grupos étnicos e culturais da Nação", por somente terem em conta as comunidades indígenas e afrodescendentes.

Quinto: o repensar das legislações pretensamente neutras, a partir da ótica do princípio da igualdade. ${ }^{36}$ Ira Katznelson observou, com relação aos Estados Unidos da época do New Deal o seguinte: ao propor-se a "GI Bill of Rights" para superar a crise de 1929, para os veteranos de guerra até 1955, os planos sociais excluíram os trabalhadores agrícolas e domésticos, as ocupações mais comuns dos negros na época, impulsionando, a criação de uma classe média branca. Como afirma o autor, uma autêntica "ação afirmativa para brancos." 37 
A discussão passa, também, pelo conceito de "racismo ambiental", ou seja, "qualquer política, prática ou diretiva que afete ou prejudique, de formas diferentes, voluntária ou involuntariamente, a pessoas, grupos ou comunidades por motivo de raça ou cor"38.

Vale dizer: as injustiças sociais e ambientais que recaem de forma desproporcional sobre etnias vulnerabilizadas, independentemente de sua intencionalidade. Nesta lógica, a "injustiça ambiental” é entendida como o "mecanismo pelo qual sociedades desiguais, do ponto de vista econômico e social, destinam a maior carga dos danos ambientais do desenvolvimento às populações de baixa renda, aos grupos raciais discriminados, aos povos étnicos tradicionais, aos bairros operários, às populações marginalizadas e vulneráveis" 39 . Singular lembrar que, nos Estados Unidos, o movimento por "justiça ambiental” teve origem entre os negros como desdobramento das lutas por direitos civis, depois da década de 1970, com o movimento contra aterros de resíduos tóxicos, que denunciou que três quartos dos aterros da região sudeste dos Estados Unidos estavam localizados em bairros habitados por negros (recorde-se, também, que, quando do furacão "Katrina”, a impossibilidade de evacuação da cidade atingiu, majoritariamente, a população negra).

Para José Maurício Arrutti, "no caso das comunidades quilombolas há, de fato, uma relação entre a população, o território e o meio ambiente que não é de natureza geral, mas específica", porque tais comunidades "não estão em um determinado território porque são pobres": a relação territorial é explicada em termos históricos e sociais, “dos quais não se pode abstrair o fato dessas populações descenderem de populações refugiadas ou marginalizadas social e economicamente pela escravidão, em territórios que, no período pós-abolição, não despertaram o interesse do capital”. (ARRUTTI, 2006, p. 40)

E exemplifica, assim, com duas comunidades quilombolas diferentes: a de Marambaia/RJ, em que houve ocupação em função do tráfico negreiro e depois abandono do território aos moradores, descendentes de escravos, em função do declínio desta economia e, posteriormente, reocupação pela Marinha, hoje em 
disputa pelo mesmo território; e as comunidades de Sapê do Norte/ES, em que a presença negra e indígena sempre foi muito forte e, que viveu, a partir da década de 1950, a ocupação predatória por madeireiras e, a partir dos anos 1970, assistiu ao deslocamento da sede da multinacional de celulose, para os municípios vizinhos, com menos infraestrutura e sem imigração europeia, fugindo do aumento do preço das terras.

Segundo o autor:

Em ambos os casos, estamos falando de territórios de refúgio, de uma forma ou de outra. De territórios marginais ao capital, cujos recursos ambientais foram mantidos relativamente preservados em função de uma exploração econômica de base tradicional, com baixo nível de mercantilização. Territórios que só estão em condições de servirem à cobiça do capital, hoje, porque estavam sob a posse de um tipo de população que não os explorou até o esgotamento. Além disso, se, por um lado, a própria presença daquelas populações naqueles territórios resulta de uma politica sistemática de escravização, baseada em critérios raciais, de outro, a ausência de políticas de regularização territorial, de acesso a serviços públicos, à justiça, à educação e à informação, que estão na base de sua expropriação atual, deve-se também ao fato deles se configurarem como territórios negros e, por isso, territórios simbólica e socialmente discriminados. Por serem ocupados por população negra, esses territórios estiveram fora das políticas de regularização, de crédito, de desenvolvimento, de saneamento, que beneficiaram outras populações, e, portanto, outros territórios. (Idem, P. 41)

Sexto: a incorporação da questão de gênero como outra face do princípio da não discriminação. Neste sentido, é comum a legislação tratar o sujeito de direito como "homem do campo" (Lei $\mathrm{n}^{\circ}$ 8.171/91) ou definir reforma agrária como sistema de relações entre o homem e o uso da terra, ou mesmo a necessidade de citação do marido dispensar a da esposa, na lei de desapropriação por utilidade pública (1941). ${ }^{40}$ Não se trata, somente, de alterar a linguagem da legislação, mas também de dar atenção à questão de gênero para definição de políticas públicas e de sujeitos de direitos. Destaque-se, nesse ponto, a luta das quebradeiras de coco babaçu, que é exemplar no sentido de questionar a divisão de trabalho e complementaridade na economia familiar, a liderança e papéis assumidos nos conflitos agrários pela terra e 
pelo babaçu, o reconhecimento da "honradez da identidade política quebradeira de coco". ${ }^{41}$

\title{
Considerações finais
}

Sérgio Costa e Guilherme Gonçalves, ao apreciar as decisões da Corte Interamericana envolvendo os Saramakas ${ }^{42}$, salientam a necessidade de "considerar o impacto de certas políticas públicas e outras formas de intervenção na articulação e rearticulação dos grupos socioculturais", lembrando que, no lugar de "um Estado ou de uma corte neutros que 'meramente' fornecem as oportunidades para certos grupos socioculturais preservarem suas identidades", é necessário considerar que "qualquer intervenção do estado e do direito redesenha o mapa das negociações de identidade", intervindo na constituição destes mesmos grupos. ${ }^{43}$

Daí porque tanto o enquadramento das "comunidades quilombolas" e de outras "comunidades tradicionais" no sistema jurídico de proteção da Convenção ${ }^{\circ}$ 169-OIT quanto as pautas hermenêuticas constitucionais que associam o art. 68 do ADCT com o art. 231 da Constituição, se, por um lado, podem ser consideradas como exitosas no sentido de afirmar uma especificidade cultural, trabalhando com o "reconhecimento cultural", por outro lado, não podem constituir, neste mesmo processo, num descuido em relação à "luta contra a discriminação racial".

Como se percebe, o estudo das "comunidades tradicionais" e uma reelaboração da "questão indígena" colocam muitos pontos de renovação para o Direito Agrário. Estes foram apenas alguns destacados.

\section{THE RENEWAL OF AGRARIAN LAW AND THE QUILOMBOS: IDENTITY, TERRITORY AND CULTURAL RIGHTS}

\begin{abstract}
The discussion involving quilombolas and traditional communities has been built gradually within the discipline of Agrarian Law. It is about considering the emergence of themes and issues that were silenced, neglected or taken as existing. Accordingly, in the intersection with legal anthropology, international human rights law and anti-
\end{abstract}


discrimination law, we seek to verify the paths of research thatenable such communities to renew the study of the Agrarian Law.

Keywords: Principle of equality. International human rights law. Traditional communities. Legal anthropology.

\section{Notas explicativas}

1 Idem, p. 511. Discussão que fica evidente quando se acentua o caráter desenvolvimentista (aumento da produção, da produtividade, desenvolvimento rural, desenvolvimento econômico), simultaneamente à conservação dos recursos naturais e da função social da terra: CARVALHO, Edson Ferreira de. Manual Didático de Direito Agrário. Curitiba: Juruá, 2010, p. 55-68.

2 O que envolve eventual desapropriação em virtude da constatação de trabalho escravo: OLIVEIRA, op cit., p. 175.

3 Idem, p. 205. Interessante observar que o autor, ao citar o art. $6^{\circ}$ do Decreto $\mathrm{n}^{\circ}$ 71.615/72- segundo o qual as "comunidades indígenas, dependendo do grau de integração" possam "participar ativamente dos referidos programas e projetos"- saliente "por que seria mais recomendável tais indígenas participarem de projetos e programas que são de terceiros,e não dos próprios índios, aos quais não se adapta o conceito de civilização?' (op. cit, p. 206). A situação soa mais paradoxal, ainda, quando se percebe que a legislação de 1972 já previa a participação dos indígenas nos projetos, e, mesmo com a Constituição de 1988, a Convenção 169-OIT e a Declaração da ONU sobre os povos indígenas, ainda há resistência, inclusive por parte dos Ministros do STF ( vide julgamento "Raposa Serra do Sol), para a consulta prévia/consentimento informado no tocante aos projetos de desenvolvimento nacional e proteção ambiental.

4 Idem, p. 87. Saliente-se que a Constituição colombiana de 1991 prevê, expressamente, a função ecológica da propriedade (art. 58.2). Nesse sentido, a Corte Constitucional na Sentencia C-126/98, M.P. Alejandro Martínez Caballero, decidiu que com a função ecológica se pretende "garantir a qualidade de vida das pessoas, a proteção dos recursos naturais e a implementação do desenvolvimento sustentável": desta forma, a função social "pretende dar-lhe um uso à propriedade que beneficie toda coletividade, e a função ecológica lo que pretende é proteger o entorno, os ecossistemas, para efetivar os direitos ambientais."

5 Idem, p. 89. Observe-se, contudo, que os referidos autores, quando analisam as "condicionantes" do julgamento "Raposa Serra do Sol" não fazem a crítica em relação a eventuais incongruências com o direito internacional, em especial a Convenção 169-OIT e a Declaração da ONU para os Povos Indígenas, de 2007 (vide p. 93-95). Da mesma forma, naquele julgamento, o STF desconsiderou "posse imemorial" (p. 99) e o próprio "indigenato", para aceitar a "teoria do fato indígena", ou seja, a efetiva ocupação em 5 de outubro de 1988.

6 Vide: ALMEIDA, Alfredo Wagner Berno de. Terras tradicionalmente ocupadas. IN: SOUZA LIMA, Antonio Carlos, coord. Geral. Antropologia \& Direito: temas antropológicos para estudos jurídicos. Brasília, Rio de Janeiro, Blumenau: ABA/LACED/Nova Letra, 2012, p. 377. 
Nota 13, p. 120-122.

8 Em que estão incluídos de representantes de agroextrativistas da Amazônia, caiçaras, comunidades de fundo de pasto, comunidades de terreiro, quilombolas, faxinais, geraizeiros, pantaneiros, pescadores artesanais, pomeranos, povos ciganos, povos indígenas, quebradeiras de coco babaçu, retireiros e seringueiros. Informações no site: http://www.mds.gov.br/acesso-a-informacao/orgaoscolegiados/orgaos-em-destaque/cnpct.

9 Assim, por exemplo, ao tratar de outros "espaços territoriais espacialmente protegidos", dentro do tópico da "função ambiental da propriedade rural", não se faz referência à existência de "populações tradicionais": BORGES, Roxana Cardoso Brasileiro. Função ambiental da propriedade rural. IN: BARROSO, Lucas Abreu, MIRANDA, Alcir Gursen de, SOARES, Mário Lúcio Quintão. O Direito Agrário na Constituição. São Paulo: Forense, 2006, p. 281-301. Importante salientar, contudo, que, no mesmo volume, Raymundo Laranjeira trata da segurança alimentar e dos transgênicos (p. 187-222), ao passo que Benedito Ferreira Marques discute o acesso à terra como condição de cidadania (p. 101-126).

10 Ligia Osorio Silva destaca que a lei de terras deveria dar ao Estado imperial o controle sobre as terras devolutas, que vinham "passando de forma livre e desordenada ao patrimônio particular", mas tal situação continuou ocorrendo, principalmente: a) por conta das sucessivas prorrogações de data de validade das posses; b) pela alteração dos prazos para revalidações de sesmarias e legitimações de posses (SILVA, Ligia Osorio. Terras devolutas e latifúndio. $2^{\mathrm{a}}$ ed. Campinas: UNICAMP, 2008, p. 356-358). A existência de grandes extensões de terras possibilitou a permanência de uma "fronteira aberta", em que o "posseiro" não era o lavrador com poucos recursos, mas sim os grandes fazendeiros do café, do algodão, etc (op. cit., 360). Para ela, "a existência do latifúndio e a da grande exploração agrícola não constituíram sobrevivências do passado, mas foram continuamente recriados” durante os séculos XIX e XX.

11 Aliás, a Lei de Terras é contemporânea da proibição do tráfico negreiro no país (Lei Eusébio de Queirós, de 1850) e, portanto, não pode ser analisada separadamente do imaginário racial da época, em que proprietários temiam revoltas escravas similares à Revolução Haitiana de 1804, ao mesmo tempo em que os abolicionistas apelavam para uma solução que evitasse uma guerra civil à imagem da ocorrida nos Estados Unidos (18611865).

12 Para uma análise das distintas situações e denominações: ALMEIDA, Alfredo Wagner Berno de. Terras de preto, terras de santo, terras de índio- uso comum e conflito. IN: Terras tradicionalmente ocupadas, op. cit, p. 133-178.

13 SOGAME, Maurício. Populações tradicionais e territorialidades em disputa. Disponivel

http://www.uff.br/posgeo/modules/xt_conteudo/content/campos/mauricio.pdf

ALMEIDA, Alfredo Wagner de. Conceito de terras tradicionalmente ocupadas. https://redeagu.agu.gov.br/UnidadesAGU/CEAGU/revista/Ano_V_novembro_2005/alfredo -indio.pdf

14 FERNANDES, Edesio. Do Código Civil ao Estatuto da Cidade: algumas notas sobre a trajetória do Direito Urbanístico no Brasil. IN: VALENÇA, Márcio Moraes (ed). Cidade ( i) legal. Rio de Janeiro: Mauad X, 2008, p. 54. Para uma análise dos processos de divisão regular, irregularidade e invasão/ilegal divisão de terras, vide também: FERNANDES, Edesio. Access to Urban Land and Housing in Brazil: "three degrees of illegality". Lincoln Institute of Land Policy, 1997, 29 p. Disponivel em: http://66.223.94.76/pubs/dl/130_Fernandes97-web.pdf. 
15 Para Boaventura Santos, as transformações políticas e institucionais em curso na América Latina apontam para um "novíssimo pluralismo jurídico", dinamizado por um "constitucionalismo transformador", que expande o campo do político para além do espectro liberal, "através de uma nova institucionalidade (plurinacionalidade), uma nova territorialidade (autonomias assimétricas), uma nova legalidade (pluralismo jurídico), um novo regime político (democracia intercultural) e novas subjetividades individuais e coletivas (indivíduos, comunidades, nações, povos, nacionalidades)" (SANTOS, Boaventura de. Para uma revolução democrática da justiça. $3^{a}$ ed. São Paulo: Cortez, p. 116).

16 Para uma parcial revisão conceitual: GONZÁLEZ CASANOVA, Pablo. Colonialismo interno. IN: Exploração, colonialismo e a luta pela democracia na América Latina. Petrópolis, Buenos Aires, Rio de Janeiro: Vozes/CLACSO/LPP, 2002, p. 82-109. Nos anos 90, o autor vai criticar o conceito de "pós-colonialismo" porque impede "captar a herança colonial, o colonialismo informal ainda vivo nas regiões da Terra dominadas pelos antigos impérios europeus e pelo mais recente, o norte-americano", escondendo, ainda, os "estranhos tipos de colonialismo interno e externo que surgiram na URSS e em outros países chamados socialistas, assim como as formas mais recentes de colonialismo transnacional e global" (GONZÁLEZ CASANOVA, Pablo. O colonialismo global e a democracia. Rio de Janeiro: Civilização Brasileira, 1995, p. 52).

17 STAVENHAGEN, Rodolfo. Siete tesis equivocadas sobre América Latina. IN: Los pueblos originairos: el debate necesario. Buenos Aires: CTA/CLACSO, 2010, p. 146-148 e 151-152. A questão já tinha sido desenvolvida também em: STAVENHAGEN, Rodolfo. Clases, colonialismo y aculturación. Guatemala: Ministerio de Educación, 1968, p. 49-64.

18 Dentre outros: cf. caso Yakye Axa Vs. Paraguai, parágrafo 143; caso Mayagna Awas Tigni Vs. Nicarágua, parágrafo 148, e caso Sawhoyamaxa vs. Paraguai, parágrafo 120. Destaque-se, nesse sentido, o reconhecimento, na Constituição equatoriana, do direito à propriedade nas formas pública, privada, comunitária, estatal, associativa, cooperativa, mista e que cumpra a função social e ambiental (art. 321) e, na Constituição boliviana, de uma economia plural, "com formas de organização econômica comunitária, estatal, privada e social cooperativa” (art. 306.II).

19 Especificamente, nos casos Moiwana (parágrafo 133) e Saramaka (parágrafo 92) , ambos contra Suriname.

20 Caso Sarayaku vs. Ecuador, parágrafo 150.

21 Caso Saramaka vs. Suriname, parágrafo 82.

22 Caso Saramaka vs. Suriname, parágrafo 115.

23 Neste sentido, é a previsão do art. 13 da atual Constituição do Equador, como acesso "seguro e permanente a alimentos sãos, suficientes e nutritivos, preferencialmente produzidos a nivel local e em correspondência com suas identidades e tradições culturais”.

24 Javier Alejandro Lifschitz (Comunidades tradicionais e neocomunidades. Rio de Janeiro: Contracapa, 2011) utiliza a denominação "necomunidades", para dar conta dos processos de interações entre agentes modernos e tradicionais (p. 184-186), e também tratar desses "territórios onde se atualizam questões como a ancestralidade, parentesco, cultura material e proximidade face a face, mas em contextos relacionais que reconfiguram a relação entre interior e exterior" ( p. 91). Para ele, o fenômeno quilombola é, em certo sentido, "pós-tradicional, porque instaura uma identidade política dessubstancializada que foi se constituindo no âmbito disperso e fragmentário das comunidades e sobre a base de diferentes lealdades religiosas e culturais" (p. 190). Tanto Javier Lifstchitz (p. 105-113) 
quanto Marcelo Moura Mello (Reminiscências dos quilombos. São Paulo: Terceiro Nome, 2012, p. 47) tem salientado a necessidade de repensar as perspectivas que, insistindo no processo de territorialização, acabam definindo os grupos étnicos a partir da perspectiva do Estado, ou seja, "o espelho estatal da etnia”.

25 Caso Saramaka vs. Suriname, parágrafos 176 e 185.

26 Opinión Consultiva OC-8/87, de 30 de janeiro de 1987, Serie A, nº 8, parágrafo 32. Reafirmado no Caso Jorge Odir Miranda Cortez y outros vs. El Salvador, 20 de março de 2009, Comissão Interamericana de Direitos Humanos, envolvendo pessoas portadoras de vírus HIV. No mesmo sentido: Caso Bámaca Velásquez vs. Guatemala, parágrafo 191 e Caso Cesti Hurtado vs. Perú, parágrafo 125.

27 SOUSA FILHO, Carlos Frederico Marés de. Os direitos invisíveis. Disponível em: http:/ / www.anpocs.org/portal/index.php?option=com docman\&task=doc view\&gid $=5240 \&$ Itemid $=360$.

28 Daí as peculiaridades da modalidade de desapropriação, prevista no Decreto $\mathrm{n}^{\circ}$ 4.887/2003: a) ela tem uma finalidade de proteção de "direitos culturais" e "territoriais" de uma comunidade específica, que, ao mesmo tempo, é reconhecida, constitucionalmente, como representante de "patrimônio cultural imaterial"; b) a expropriação não se dá para transferência da propriedade individual para o domínio do Estado, mas sim o Estado "apaga" o título anteriormente existente, para que, em seu lugar, seja titulada a propriedade em "nome coletivo" para a comunidade ( em nenhum momento a propriedade passa do particular para o Estado); c) a propriedade, que antes se admitia plena e incondicional, passa, a partir do reconhecimento formal, a se atribuir publicamente e sem qualquer outra formalidade, ou seja, não se busca a declaração da aquisição da propriedade, mas a publicização da propriedade preexistente. Vide, nesse sentido: CASTILHO, Manoel Lauro Volkmer de. Parecer AGU/MC 1/2006. IN: DUPRAT, Deborah (org). Pareceres juridicosdireitos dos povos e das comunidades tradicionais. Manaus: UEA, 2007, p. 54. Disponível em: http://ccr6.pgr.mpf.gov.br/documentos-e-publicacoes/artigos/documentose- publicacoes/docs_artigos/Parecer_AGU_01_2006.pdf.

29 Foi o que sucedeu quando a Corte Constitucional colombiana, na citada Sentencia C-169, de 2001, M.P. Carlos Gaviria Díaz, afirmou que os direitos coletivos das comunidades negras, para efeitos de aplicação da Lei $\mathrm{n}^{\circ}$ 70/93 ("terras de comunidades negras") se davam em função de seu status de "grupo étnico" e não da cor de pele, o que equivaleria a dizer que "os afro-colombianos que não pertencem às comunidades negras sofrem uma dupla discriminação: socialmente, por serem negros em termos raciais, e, legalmente, por não serem suficientemente negros em termos étnicos." (ARIZA, Libardo José. Derecho, saber e identidad indigena. Bogotá: Siglo del Hombre, 2009, p. 315.)

30 Vide a discussão de João Pacheco de Oliveira a respeito da história oral: Os caxixós do Capão do Zezinho: uma comunidade indigena distante de imagens da primitividade e do indio genérico. Disponível em: nai.org.br/arquivos/Laudo_Antropologico_Caxixos_Capao.pdf

$31 \quad$ AI n ${ }^{\circ}$ 2005.04.01.052760-4/RS, Rel. Juiz Márcio Antônio Rocha, convocado, julg. 1907-2006. Posteriormente, a sentença de primeiro grau decidiu em sentido contrário.

32 CASTILHO, Ela Wiecko V. de. Processo civil e igualdade étnico-racial. IN: PIOVESAN, Flávia \& SOUZA, Douglas Martins de. Ordem jurídica e igualdade étnico-racial. Rio de Janeiro: Lumen Juris, 2008, p. 295-299. A possibilidade foi admitida como conveniente no julgamento do AI no 2008.04.00.010160-5/PR (Rel. Desembargadora Federal Maria Lúcia Luz Leiria, julg. 01-07-2008, publ. DE 31-07-2008). 
33 Sentencia C-624, de 2008, M.P. Humberto Antonio Sierra Porto.

34 Sentencia C-864/2008, M.P. Marco Gerardo Monroy Cabra.

35 Sentencia C-359/13, M. P. Iván Palacio Palacio. 20 de junho de 2013.

36 Para uma análise do direito da discriminação, direta e indireta, tanto na aplicação do direito quanto na concepção: RAUPP RIOS, ROGER. Direito da antidiscriminação; discriminação direta, indireta e ações afirmativas. Porto Alegre: do Advogado, 2008.

37 KATZNELSON, Ira. New Deal, Raw Deal. How Aid Became Affirmative Action for Whites. Washington Post, September, 27, 2005, page A23. Disponível em: http://www.washingtonpost.com/wp-

dyn/content/article/2005/09/27/AR2005092700484.html.. Ver também: HORWITT, Sanford D. The raw deal coiled in the New Deal. San Francisco Chronicle, August 28, 2005, page C1. Disponivel em: http://www.sfgate.com/cgibin/article.cgi?file=/c/a/2005/08/28/RVGOSEA4JK1.DTL\&type=printable .

38 BULLARD, Robert. Ética e racismo ambiental. Disponível em: http://www.sfiec.org.br/iel/bolsaderesiduos/Artigos/Artigo_Etica_e_Racismo_Ambiental.pd $\mathrm{f}$

39 Manifesto de lançamento da Rede Brasileira de Justiça Ambiental. Disponível em: http://www.justicaambiental.org.br/_justicaambiental/pagina.php?id=229

$40 \quad$ Ponto destacado por MARÉS \& MARÉS, op. cit, p. 182.

41 Vide a análise da questão em: FIGUEIREDO, Luciene Dias. Empates nos babaçuais: do espaço doméstico ao espaço público. Lutas de quebradeiras de coco babaçu no Maranhão. IN: WOORTMANN, Ellen et allii. Margarida Alves: II Coletânea sobre Estudos Rurais e Gênero. Brasília: MDA/NEAD, 2007, p. 59-78. Uma atenção tem sido dada para a discussão do trabalho de crianças entre as quebradeiras: SOUSA, Emilene Leite de. Infância em pedaços: o trabalho das crianças quebradeiras de coco babaçu no Maranhão. Disponível em:

http://www.fazendogenero.ufsc.br/9/resources/anais/1278293709_ARQUIVO_Quebrando ainfancia.pdf.

42 COSTA, Sérgio \& GONÇALVES, Guilherme Leite. Human Rights as Collective Entitlement? Afro-Descendants in Latin America and the Caribbean. In: Zeitschrift für Menschenrechte, 2/2011, p. 69. Os autores ainda enfatizam que as decisões mais recentes da Corte acabam por caracterizar as comunidades como ahistóricas e "cuja existência supostamente não mudou nos últimos três séculos" (op.cit, p. 64), ao mesmo que em criticam que, ao determinar a criação de um fundo de reparações administrados, em parte dos estranhos à comunidade, supõe que "a necessidade de proteção dos marroons beneficiados deriva, ao mesmo tempo, da representação de sua humanidade e de sua especial fragilidade", ou seja, "sob o manto de um discurso humanista, identidades, assimetrias e dominações são fixas"(op. cit., p. 63). Sobre as "consequências profundas e provavelmente irreversíveis" das decisões de indenização em dinheiro, vide: RODRÍGUEZ GARAVITO, César.. Etnicidad.gov; los recursos naturales, los pueblos indigenas y el derecho a la consulta previa en los campos sociales minados. Bogotá: Centro de Derecho, Justicia y Sociedad, DeJusticia, 2012, p. 57-61.

43 A crítica de Costa é quanto ao risco, “inerente às políticas multiculturalistas" de que, "com intenção de preservar a cultura associada aos afrodescendentes em sua suposta forma originária, dificultam os processos dinâmicos de intercâmbio e difusão que conferem vitalidade e perenidade às diferentes formas de expressão cultural.”(COSTA, Sérgio. 
Perspectivas y políticas sobre racismo y afrodescendencia en América Latina y el Caribe. IN: HOPENHAYN, Martín \& SOJO, Ana. Sentido de pertinencia en sociedades fragmentadas. Buenos Aires: Siglo XXI, 201 1, p. 267.

\section{Referências}

ALFONSIN, Jacques Távora. O acesso à terra como conteúdo de direitos humanos fundamentais à alimentação e à moradia. Porto Alegre: Sergio Fabris, 2003.

ALMEIDA, Alfredo Wagner Berno de \& SOUZA, Roberto Martins de. Terras de faxinais. Manaus: UEA, 2009.

ALMEIDA, Alfredo Wagner Berno de. Terras tradicionalmente ocupadas: processos de territorialização, movimentos sociais e uso comum. IN: Terras de quilombo, terras indigenas, "babaçuais livres", "castanhais do povo", faxinais e fundos de pasto: Terras tradicionalmente ocupadas. $2^{a}$ ed. Manaus: PGSCA e UFAM, 2008.

. Conceito de terras tradicionalmente ocupadas. https://redeagu.agu.gov.br/UnidadesAGU/CEAGU/revista/Ano V novembro 2005 Lalfredo-indio.pdf

ANDRADE, Maristela de Paula. Terra de indio; identidade étnica e conflito de

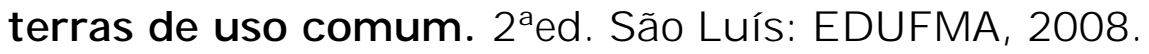

ARIZA, Libardo José. Derecho, saber e identidad indígena. Bogotá: Siglo del Hombre, 2009.

ARRUTTI, José Mauricio Andion. Qual a contribuição do debate sobre comunidades quilombolas para o debate do racismo ambiental? IN: HERCULANO, Selene \& PACHECO, Tania. Racismo ambiental- I Seminário Brasileiro contra o Racismo Ambiental. Rio de Janeiro: FASE, 2006.

ATAÍDE JR., Wilson Rodrigues. Os direitos humanos e a questão agrária no Brasil. Brasília: UNB, 2006.

CACCIAMALI, Maria Cristina \& AZEVEDO, Flávio Antonio Gomes de. Entre o tráfico humano e a opção da mobilidade social: a situação dos imigrantes bolivianos na cidade de São Paulo. IN: CERQUEIRA, Gelba Cavalcante et allii. Trabalho escravo contemporâneo no Brasil. Rio de Janeiro: UFRJ, 2008.

CARVALHO, Edson Ferreira de. Manual Didático de Direito Agrário. Curitiba: Juruá, 2010.

CARVALHO, Franklin Plessman de. Terras tradicionalmente ocupadas: estudo comparativo entre comunidades de fundo de pasto e seus respectivos processos de 
regularização fundiária. IN: SAUER, Sérgio \& ALMEIDA, Wellington (org). Terras e territórios na Amazônia: demandas, desafios e perspectivas. Brasília: UNB, 2011.

CASANOVA, Pablo González. A democracia no México. Rio de Janeiro: Civilização Brasileira, 1967.

. Colonialismo interno. IN: Exploração, colonialismo e a luta pela democracia na América Latina. Petrópolis, Buenos Aires, Rio de Janeiro: Vozes/CLACSO/LPP, 2002.

Civilização Brasileira, 1995.

O colonialismo global e a democracia. Rio de Janeiro:

CASTILHO, Ela Wiecko V. de. Processo civil e igualdade étnico-racial. IN: PIOVESAN, Flávia \& SOUZA, Douglas Martins de. Ordem jurídica e igualdade étnico-racial. Rio de Janeiro: Lumen Juris, 2008.

CASTILHO, Manoel Lauro Volkmer de. Parecer AGU/MC 1/2006. IN: DUPRAT, Deborah (org). Pareceres jurídicos- direitos dos povos e das comunidades tradicionais. Manaus: UEA, 2007, p. 54. Disponivel em: http://ccr6.pgr.mpf.gov.br/documentos-e-publicacoes/artigos/ documentos-epublicacoes/docs_artigos/Parecer_AGU_01_2006.pdf.

COSTA, Alexandre Emboaba. Mobilizando a ancestralidade afro-brasileira para a transformação das relações sociais e o desenvolvimento global. 2010. Disponivel em: http://www.orunmila.org.br/blog/?p=167.

COSTA, Sérgio \& GONÇALVES, Guilherme Leite. Human Rights as Collective Entitlement? Afro-Descendants in Latin America and the Caribbean. In: Zeitschrift für Menschenrechte, 2/2011.

COSTA, Sérgio. Perspectivas y políticas sobre racismo y afrodescendencia en América Latina y el Caribe. IN: HOPENHAYN, Martín \& SOJO, Ana. Sentido de pertinencia en sociedades fragmentadas. Buenos Aires: Siglo XXI, 2011.

DULITZKY, Ariel E. Cuando los afrodescendientes se transformaron em 'pueblos tribales'. El sistema interamericano de derechos humanos y las comunidades rurales negras. Bogotá: ILSA,. El otro derecho,41, mayo 2010, p. 30. Disponível em: http://ccr6.pgr.mpf.gov.br/documentos-e-publicacoes/artigos/document.2006$\underline{04-04.1440775161}$

FIGUEIREDO, Luciene Dias. Empates nos babaçuais: do espaço doméstico ao espaço público. Lutas de quebradeiras de coco babaçu no Maranhão. IN: WOORTMANN, Ellen et allii. Margarida Alves: II Coletânea sobre Estudos Rurais e Gênero. Brasília: MDA/NEAD, 2007. 
GARCÍA, Helena Alviar. La redistribución de la propiedad en América Latina: ¿ Debemos perder la fe em el derecho? Revista Internacional de Pensamiento Político, v. 5, 2001.

GOMES, Lilian Cristina Bernardo. Justiça seja feita: direito quilombola ao território. Belo Horizonte: UFMG, 2009 (Tese de Doutorado em Ciência Política). . Justiça seja feita: direito quilombola ao território. IN: ALMEIDA, Alfredo Wagner Berno de et alii (org). Territórios quilombolas e conflitos. Manaus: UEA, 2010 (Caderno de Debates Nova Cartografia social, vol. 01, $\mathrm{n}^{\circ} 02$.

GROSSI, Paolo. A propriedade e as propriedades na oficina do historiador. IN: História da propriedade e outros ensaios. Rio de Janeiro: Renovar, 2006.

HOLSTON, James. Legalizando o ilegal: propriedade e usurpação no Brasil. Revista Brasileira de Ciências Sociais, (21): 80, fevereiro de 1993.

LARANJEIRA, Raymundo. Direito Agrário; perspectivas críticas. São Paulo: LTR, 1984, p. 16. Para um levantamento das discussões conceituais, em especial no direito nacional: OLIVEIRA, Umberto Machado de. Principios de direito agrário na Constituição vigente. Curitiba: Juruá, 2004.

LIFSCHITZ, Javier Alejandro. Comunidades tradicionais e neocomunidades. Rio de Janeiro: Contracapa, 2011.

LYRA FILHO, Roberto. Direito do capital e Direito do Trabalho. Porto Alegre: Fabris, 1982.

MACHADO, Jónatas. Liberdade religiosa numa comunidade constitucional inclusiva. Coimbra: Coimbra Editora, 1996.

MARÉS, Carlos \& MARÉS, Theo. Direito agrário e Igualdade Étnico-Racial. IN: PIOVESAN, Flávia \& SOUZA, Douglas Martins de. Ordem Jurídica e Igualdade Étnico-Racial. Brasília: SEPPIR, 2006.

MARICATO, Ermínia. As idéias fora do lugar e o lugar fora das idéias. IN: ARANTES, Otília, VAINER, Carlos \& MARICATO, Ermínia. A cidade do pensamento único: desmanchando consensos. Petrópolis: Vozes, 2000.

MARQUES, Benedito Ferreira. Direito Agrário brasileiro. $7^{\text {a }}$ ed. rev. ampl. São Paulo: Atlas, 2007.

MELLO, Marcelo Moura. Reminiscências dos quilombos. São Paulo: Terceiro Nome, 2012. 
MERRY, Sally Engle. Pluralismo jurídico. IN: BONILLA MALDONADO, Daniel et alii, org. Pluralismo jurídico. Bogotá: Siglo del Hombre/Universidad de los Andes/Javeriana, 2007.

MOREIRA, Vânia Maria Losa. Usos do passado: a questão quilombola entre história, a memória e a política. IN: SOIHET, Rachel, ALMEIDA, Maria Regina Celestino de, AZEVEDO, Cecília \& GONTIJO, Rebeca. Mitos, projetos e práticas políticas; memória e historiografia. Rio de Janeiro: Civilização Brasileira, 2009.

QUIJANO, Aníbal. Colonialidade do poder e classificação social. IN: SANTOS, Boaventura de Sousa \& MENESES, Maria Paula (org). Epistemologias do Sul. São Paulo: Cortez, 2010.

Sociedad y Politica, 1988.

Modernidad, identidad y utopía en América Latina. Lima:

RIOS, Roger Raupp. Direito da antidiscriminação; discriminação direta, indireta e ações afirmativas. Porto Alegre: do Advogado, 2008.

. O princípio da igualdade e o direito da antidiscriminação: discriminação direta, discriminação indireta e ações afirmativas no direito constitucional estadunidense. Tese de doutorado, UFRGS, 2004.

- O princípio da igualdade na jurisprudência do Supremo Tribunal Federal: argumentação, força normativa, direito sumular e antidiscriminação. IN: SARMENTO, Daniel \& SARLET, Ingo Wolfgang. Direitos fundamentais no Supremo Tribunal Federal: balanço e crítica. Rio de Janeiro: Lumen Juris, 2011.

ROCHA, Ibraim, TRECCANI, Girolamo Domenico, BENATI, José Heder, HABER, Lilian Mendes, CHAVES, Rogério Arthur Friza. Manual de Direito Agrário Constitucional; lições de Direito agroambiental. Belo Horizonte: Fórum, 2010.

ROCHA, Otávio Gomes. Mobilização e resistência dos povos faxinalenses: contribuições da Cartografia social como instrumento de protesto. IN: FEREZ, Cecilia Abdo, GALVANI, Mariana, PIERBATISTI, Damián \& RODRÍGUEZ, María Carla, compiladores. Nuevos horizontes en la investigación social. Buenos Aires: CLACSO, 2013.

SALAZAR, Juan García et all. Territorios, territorialidad y desterritorialización; un ejercício pedagógico para reflexionar sobre los territorios ancestrales. Quito: ALTROPICO- Fundación para el Desarrollo de Alternativas Comunitarias de Conservación del Trópico, 2010. 
SANTOS, Boaventura de Sousa. Para além do pensamento abissal: das linhas gerais globais a uma ecologia de saberes. Revista Crítica de Ciências Sociais, (78): outubro de 2007.

Paulo: Cortez, 2007.

. Para uma revolução democrática da justiça. São . Para uma sociologia das ausências e uma sociologia das emergências. Disponível em: http://rccs.revues.org/1285.

SHIRASHI NETO, Joaquim. "Crise" nos padrões jurídicos tradicionais: o direito em face dos grupos sociais portadores de identidade coletiva. Disponível em: http://www.conpedi.org.br/manaus/arquivos/anais/XIVCongresso/005.pdf

SILVA, Ligia Osorio. Terras devolutas e latifúndio. $2^{\mathrm{a}} \mathrm{ed}$. Campinas: UNICAMP, 2008.

SODERO, Fernando Pereira. Esboço histórico da formação do direito agrário no Brasil. Rio de Janeiro: AJUP-FASE, junho de 1990.

SOGAME, Maurício. Populações tradicionais e territorialidades em disputa. Disponivel em: http://www.uff.br/posgeo/modules/xt conteudo/content/campos/mauricio.pdf

SOUSA FILHO, Carlos Frederico Marés de. Direito agrário e meio ambiente. IN: LARANJEIRA, Raymundo (coord). Direito agrário brasileiro. São Paulo: LTR, 1999.

STAVENHAGEN, Rodolfo. Clases, colonialismo y aculturación. Guatemala: Ministerio de Educación, 1968.

. Siete tesis equivocadas sobre América Latina. IN: Los pueblos originairos: el debate necesario. Buenos Aires: CTA/CLACSO, 2010.

WEINGARTNER NETO, Jayme. Liberdade religiosa na Constituição. Porto Alegre: do Advogado, 2007.

Artigo submetido para avaliação em 12 de setembro de 2013 e aceito para publicação em 15 de novembro de 2013. 